\title{
Determining the Phytochemical Parameters of Pisum sativum (pease) and Effects on the Development of Debaryomyces hansenii
}

\author{
Pınar Erecevit ${ }^{1 *}$, Sevda Kırbağ ${ }^{2}$ \\ 1'Department of The Food Processing, Pertek Sakine Genç Vocational School, Munzur University, TR 62000-Tunceli, TURKEY. \\ ${ }^{2}$ Department of Biology, Science Faculty, Fırat University, TR 23119-Elazığ, TURKEY.
}

\begin{abstract}
Objective: In this work; phytochemical parameters (fatty acid, vitamin, phytosterol, flavonoid and resveratrol contents, and antioxidant activities antimicrobial activities) of Pisum sativum (pease) extracts prepared with Debaryomyces hansenii were detected. $P$. sativum (pease) is known as one of the nutritional sources of prebiotics. Methods: Phytochemical contents of extracts were evaluated with device and assays like Shimadzu 17, Shimadzu brand HPLC, Spectrophotometer device and well agar methods respectively. Results: it was observed that total fatty acid, flavonoid, contents in pease extracts were at low levels and vitamin, and phytosterol contents were at changing. It was detected that total fatty acid, vitamin and phytosterol contents; at significant rates of pease extracts prepared with $D$. hansenii; however, flavonoid contents decreased at different rates. In the work, it was noticed that pease had increasingly antioxidant activities and antimicrobial activities at changing rates, acordingly at fatty acid, vitamin and phytosterol levels; at significant rates increased. On the other hand, flavonoid extracts demonstrated scarcely any antimicrobial activity. When antimicrobial activities of pease extracts containing $D$. hansenii were analyzed, they had effect at increasing rates of fatty acid, vitamin and phytosterol. On the other hand, it was demonstrated that flavonoid extracts did not have any antimicrobial activity against all of the microorganisms except Bacillus megaterium DSM 32. Conclusion: it was detected that pease which is known as prebiotic food, can be used in terms of proper prebiotic and the relationship of proper prebiotic-prebiotic (symbiotic) for the development of $D$. hansenii used in this study which is also accepted as probiotic yeast. It was observed that this yeast type developing in extracts obtained from pease affected other beneficial nutrients such as vitamins, minerals, phenolic compounds at varying rates.
\end{abstract}

Key words: Debaryomyces hansenii, Pisum sativum (pease), Symbiotic, Phenolic compounds.

\section{INTRODUCTION}

People need to have a functional, balanced gastrointestinal system (GIS) in terms of 'beneficial' and 'harmful' microorganisms to live a healthy life. These are also ensured by intestinal microflora. ${ }^{1}$ The intestinal microflora participates in several intestinal metabolic issues and immune modulation besides its positive effects on protecting the host by preventing the colonization and proliferation of pathogenic microorganisms. ${ }^{2,3,4}$ Therefore, giving directly the nutrition elements which are one of the essential components of microflora and provides to proliferation of yeasts and filamentous (probiotic) as food or both of them together (symbiotic) has been becoming an interesting treatment type in recent years. ${ }^{4,5}$

Prebiotics are short chain carbohydrates that are non-digestible by digestive enzymes in humans and selectively enhance the activity of some groups of beneficial bacteria. In
Submission Date: 17-04-2017; Revision Date: 02-07-2017; Accepted Date: 21-11-2017.

DOI: 10.5530/ijper.51.4s.93 Correspondence: Dr. PInar Erecevit, Department of The Food Processing, Pertek Sakine Genç Vocational School, Munzur University, TR 62000-Tunceli, TURKEY. Phone no. +90 42865133 $51 / 127$

E-mail: perecevit@munzur. edu.tr

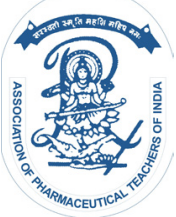

www.ijper.org 
the intestine, prebiotics are fermented by beneficial bacteria to produce short chain fatty acids. ${ }^{6}$

The Pease that has a high fiber content is one of the nutritional sources of prebiotics. ${ }^{7,8}$ However, previous studies have suggested that strains of Debaryomyces bansenii may offer promising probiotic traits relevant for further study. ${ }^{9,10}$

It was researched in this work that to develop the probiotic yeast (D. hansenii) minimal nutrient media of the extract that is prepared by P. sativum (Pease) and the effects of this plant extract on the development of $D$. hansenii and then some phytochemical parameters were compared as well.

\section{MATERIALS AND METHODS}

The Pease samples used in this study were obtained from Elazig city in Turkey. Samples were conserved in deep freezer at $-20^{\circ} \mathrm{C}$ until they were extracted.

\section{Extraction of Lipids}

Wet weight of cell pellets was determined and then they were homogenized with 3/2 (v/v) Hexane-Isopropanol mixture. After the homogenate was centrifuged at $5000 \mathrm{rpm}$ at $4 \mathrm{C}^{\circ}$ for $5 \mathrm{~min}$, supernatant part was used for fatty acid and ADEK vitamin analysis. ${ }^{11}$

\section{Preparation of Fatty Acid Methyl Esters}

A sample of $5 \mathrm{ml}$ was taken from supernatant part and $5 \mathrm{ml}$ of $2 \%$ methanolic sulfuric acid was added to it. After it was vortexed, it was left at $50^{\circ} \mathrm{C}$ for $12 \mathrm{~h}$ and then after it was cooled down to room temperature, 5 $\mathrm{ml}$ of $5 \%$ sodium chloride $(\mathrm{NaCl})$ solution was added and the mixture was vortexed again. Fatty acid methyl esters were extracted with $5 \mathrm{ml}$ of hexane. After this mixture was treated with $5 \mathrm{ml}$ of $2 \% \mathrm{KHCO}_{3}$ solution, hexane phase was evaporated with nitrogen flow and the mixture was analyzed after it was dissolved in $1 \mathrm{ml}$ of hexane. Analysis of fatty acid methyl esters was performed on SHIMADZU GC 17 device. ${ }^{12,13}$

\section{HPLC Analysis of ADEK Vitamins and Sterol Amount}

Five percent $\mathrm{KOH}$ solution was added onto a sample of $5 \mathrm{ml}$ taken from the supernatant part, vortexed, and then kept at $85 \mathrm{C}^{\circ}$ for $15 \mathrm{~h}$. Later, the mixture was cooled down to room temperature and was added $5 \mathrm{ml}$ of distilled water and then vortexed. After lipophilic molecules were treated with $2 \times 5 \mathrm{ml}$ hexane, the hexane in the medium was removed. Later, it was dissolved in $1 \mathrm{ml}$ of $(1: 1, \mathrm{v} / \mathrm{v})$ acetonitrile/methanol mixture and analyzed with Shimadzu brand HPLC device. ${ }^{14}$ Chromatograms were recorded at at $320 \mathrm{~nm}$ for retinol (vitamin A) and retinol acetate and $215 \mathrm{~nm}$ for $\delta$-tocopherol, vitamin $\mathrm{D}, \alpha$-tocopherol, $\alpha$-tocopherol acetate, $202 \mathrm{~nm}$ for phytosterols, $265 \mathrm{~nm}$ for vitamin K1. Identification of the individual vitamins and phytosterols was performed by frequent comparison with authentic external standard mixtures analyzed under the same conditions. ${ }^{15}$ The results of analyses were expressed as $\mu \mathrm{g} / \mathrm{lg}$ for each sample.

\section{Statistical Analysis}

SPSS 15.0 software was used for statistical analysis of the data. Analysis of variance (ANOVA) and least significant difference (LSD) tests were also used for comparisons of groups and the control group.

\section{DPPH Radical Scavenging Activity}

Free radical $25 \mathrm{mg} / \mathrm{L}$ DPPH ( $\alpha, \alpha$-Diphenyl- $\beta$ picrylhydrazyl) methanolic solution was prepared. During the experiment, pease sample at $25,50,100$, and $250 \mu \mathrm{L}$ concentrations were added onto $3.9 \mathrm{ml}$ methanolic solution of DPPH radical, vortexed, and then incubated in a dark environment at room temperature for $30 \mathrm{~min}-$ Absorbance values were read against a blank at $517 \mathrm{~nm}$ using a spectrophotometer. ${ }^{16,17}$ Radical scavenging activity was calculated as \%. DPPH radical scavenging activity was calculated by using $(\%)=[($ Control $\lambda-$ Sample $\lambda) /$ (Controli)] x 100 formula.

\section{Determination of Resveratrol and Flavonoid Contents}

Flavonoid and resveratrol analysis was conducted on HPLC device and all operations were performed at $25^{\circ} \mathrm{C} .{ }^{18}$

\section{Extraction and analysis of phytosterols}

Five percent $\mathrm{KOH}$ was added onto the Pease sample which was homogenized with hexane/isopropanol alcohol mixture (at $3 / 2 \mathrm{v} / \mathrm{v}$ ratio) and then it was hydrolyzed at $85^{\circ} \mathrm{C}$. Extraction was treated with $\mathrm{n}$-heptane and analyzed with HPLC device.

\section{Sugar Analysis}

$10 \mathrm{~g}$ Pease sample was homogenized with distilled water. Then, supernatant part was separated from the pellet. After total filtrate volume was determined, it was analyzed with HPLC device and Shim-Pack HRC NH2 $(150 \times 4.6 \mathrm{~mm}, 5 \mu$.) column was used. Acetonitrile + Water (v/v) (\%75/\%25) mixture was used as mobile phase. $^{19}$

\section{Antimicrobial activity}

Test Microorganisms

A total of $2 \mathrm{~g}+$ bacteria (Staphylococcus aureus COWAN 1, Bacillus megaterium DSM 32), 2g- bacteria 
(Escherichia coli ATCC 25922, Klebsiella pneumoniae FMC 5), 2 yeasts (Candida albicans FMC 17, Candida glabrata ATCC 66032) and 2 dermatophyte species (Trichophyton sp., Epidermophyton sp.) were used in the current research. Microorganisms were provided from the Department of Biology, Firat University, Microbiology Laboratory, Elazig-Turkey.

\section{Well Agar Method}

Antimicrobial tests were carried out by the well agar method using $100 \mu \mathrm{L}$ of suspension containing $10^{6}$ cells / $\mathrm{mL}$ of bacteria, $10^{4}$ cells / $\mathrm{mL}$ yeast and cells / $\mathrm{mL}$ dermatophyte fungi as per McFarland standard, inoculated into Mueller Hinton Agar (Difco), Malt Extract Agar (Difco), and Sabouroud Dextrose Agar (Oxoid), respectively. Wells were prepared in the plates with the help of cork-borer $(0.85 \mathrm{~cm}) .10 \mu$ l of the flavonoids, vitamins and fatty acids in plants were introduced directly in to the well. Sterilized petri dishes $(9 \mathrm{~cm}$ diameter) were placed at $4^{\circ} \mathrm{C}$ for $2 \mathrm{~h}$. Then, the inoculated plates were incubated at $37 \pm 0.1^{\circ} \mathrm{C}$ at $24 \mathrm{~h}$ for bacterial strains and also at $25 \pm 0.1^{\circ} \mathrm{C}$ at $72 \mathrm{~h}$ for yeast and dermatophyte fungi. Antimicrobial activity was evaluated by measuring the zone of inhibition against the test organisms. ${ }^{20,21}$ Wells injected with methanol and hexane served as negative controls. The experimental studies were replicated three times.

\section{Development of Debaryomyces hansenii and its Prepared with $\boldsymbol{P}$. sativum (Pease) Extract}

D. hansenii was cultivated in Yeast Malt Extract Boillon for its development and reproduction. After absorbance values were read at $517 \mathrm{~nm}$ at spectrophotometer, $1 \%$ $S$. boulardii culture in bouillon $\left(10^{4}\right.$ yeast $\left./ \mathrm{ml}\right)$ was inoculated into prepared minimal well $(0,019 \mathrm{M} \mathrm{NaCl}, 0,022$ $\mathrm{M} \mathrm{KH}_{2} \mathrm{PO}_{4}, 0,049 \mathrm{M} \mathrm{Na}_{2} \mathrm{HPO}_{4}, 0,019 \mathrm{M} \mathrm{NH}_{4} \mathrm{Cl}, 0,002$ $\mathrm{M} \mathrm{MgSO}_{4}, 0,011$ M Glucose) ${ }^{22}$ with Pease extract under sterilized conditions and appropriate $\mathrm{pH}$ level (4.8) was maintained. Extracts developed in the minimal well were collected for living cell count after they were read at 6 h., 12 h., 24 h., 36 h., 48 h., 60 h., and 72 h. at 517 nm on the spectrophotometer; then they were cultivated in Malt Extract Agar and left for incubation and colony counts were examined. Samples were centrifuged when development had stopped and pellets were collected. Fatty acid, vitamin, flavonoid, and resveratrol levels and antimicrobial activities of these pellets were analyzed. As a control group, same operations were applied on D. hansenii and Pease developed only in minimal well and comparisons were made. The study was performed with 3 parallel experiments.

\section{RESULTS}

\section{Sugar Contents}

When sugar analysis results of Pease extract was examined Table.1, it was observed that fructose, saccarose contents in the $P$. sativum extract was at significant levels $(\mathrm{p}<0.0001, \mathrm{p}<0.001)$.

\section{Fatty acids and Lipide-Soluble Vitamins and Sterol Contents}

\section{Fatty acids}

When fatty acid contents of $P$. sativum extracts were analyzed Table.2 it was observed that palmitoleic $\operatorname{acid}(16: 1)$ and linolenic acid (18:3) were not present but, palmitic acid (16:0), stearic acid (18:0), oleic acid $(18: 1 \mathrm{n} 9)$, linoleic acid $(18: 2)$ were present and it contained 16:0 at high level, $(18: 0),(18: 1 \mathrm{n} 9),(18: 2)$ at low levels $(\mathrm{p}<0.0001)$. It was detected that 16:0, 18:0, 18:1, 18:2, 18:3 levels in the pease extracts treated with $D$. hansenii signifcant and 16:1 at partly increased with compared to control group pease and $D$. hansenii. The increases in fatty acids levels indicates that $D$. hansenii, which is accepted to be a probiotic, symbiotically exists with $P$. sativum extract and being affected by the carbon source in the medium, it activates the enzymes responsible for fatty acid synthesis. Thus it is determined that based on the increase in fatty acid content, this kind of environment is detected to nourish the development of D. hansenii. Therefore, it was concluded that supporting the development of $D$. hansenii, this medium exhibited increases in fatty acid content.

\section{Lipide-Soluble Vitamins and Sterol Contents}

When $P$. sativum extracts were analyzed in terms of their vitamin and phytosterol contents Table.3, it was detected that $K_{1}, K_{2}, D$ vitamins $\delta$ - tocopherol $\alpha$ - tocopherol, retinol, phytosterols; ergosterol, stigmasterol, $\beta$-sitosterol were present in the extracts but retinol acetate was not present. When compared to the control group pease and $D$. hansenii, it was detected that in $P$. sativum extracts prepared with $D$. hansenii, $\mathrm{K}_{1}, \mathrm{~K}_{2}, \mathrm{D}$ vitamins, $\beta$-sitosterol, stigmasterol amounts increased to significantly high levels $(p<0.001), \alpha$-tocopherol, $\delta$ - tocopherol, ergosterol amounts on the other hand increased to more significantly high levels $(p<0.0001)$, and retinol acetate amount increased to low level $(p<0.05)$, while retinol amount decreased $(p<0.01)$.

It is thought that the decrease in the level of vitamins is the consumption by the yeast, and the increase in the values of other vitamins is based on D. hansenii. Based on these increased results, it is determined that $P$. sativum has a positive impact on $D$. hansenii development. According to this finding, it is suggested that 


\begin{tabular}{|c|c|c|c|c|c|}
\hline \multicolumn{7}{|c|}{ Table 1: Sugar Contents of Pease extract. } \\
\hline Sugars & Arabinose & Fructose & Glucose & Saccarose & Maltose \\
\hline Pease & - & $0.123 \pm 0.00$ & $0.0030 \pm 0.00$ & $0.0785 \pm 0.00$ & $0.0094 \pm 0.0001$ \\
\hline
\end{tabular}

\begin{tabular}{|c|c|c|c|}
\hline \multicolumn{4}{|c|}{ Table 2: Fatty acid levels of P. sativum (Pease) prepared with D. hansenif $(\boldsymbol{\mu g} / \mathbf{1} \mathbf{~ g})$} \\
\hline $\mathbf{0}$ & P+ DH & P & DH \\
\hline $16: 0$ & $126.00 \pm 3.05^{\text {cd }}$ & $82.10 \pm 0.05$ & $49.00 \pm 0.35$ \\
\hline $16: 1$ & $27.10 \pm 0.05^{c}$ & - & - \\
\hline $18: 0$ & $61.00 \pm 5.42^{\text {d }}$ & $16.16 \pm 0.08$ & $30.00 \pm 0.34$ \\
\hline $18: 1$ & $109.21 \pm 7.06^{\text {cd }}$ & $25.20 \pm 0.05$ & $54.36 \pm 0.38$ \\
\hline $18: 2$ & $470.51 \pm 16.38^{\text {cd }}$ & $47.23 \pm 0.28$ & $68.70 \pm 0.55$ \\
\hline $18: 3$ & $60.10 \pm 4.75^{\text {cd }}$ & - & - \\
\hline Total $\mu \mathrm{g} / 1 \mathrm{~g}$ & $854.00 \pm 22.19^{\text {cd }}$ & $171.00 \pm 0.37$ & $201.25 \pm 1.54$ \\
\hline
\end{tabular}

P:Pease, DH: D. hansenii, $\mathrm{P}+\mathrm{DH}$ : Pease + D. hansenii, $c d: \mathrm{p}<0.0001, \mathrm{~d}: \mathrm{p}<0.001, \mathrm{c}: \mathrm{p}<0.01, \mathrm{~b}: \mathrm{p}<0.05, \mathrm{a}: \mathrm{p}>0.05$

\begin{tabular}{|c|c|c|c|}
\hline $\begin{array}{l}\text { Lipophilic vitamins and } \\
\text { phytosterols }\end{array}$ & $P+D H$ & DH & $\mathbf{P}$ \\
\hline Vitamin K1 & $0.0136 \pm 0.0003^{d}$ & $0.0018 \pm 0.0001^{b}$ & $0.0024 \pm 0.0003$ \\
\hline Vitamin $\mathrm{K}_{2}$ & $0.0003 \pm 0.00^{d}$ & $0.0031 \pm 0.00^{\text {cd }}$ & $0.0015 \pm 0.0008$ \\
\hline Vitamin D & $0.014 \pm 0.0003^{d}$ & $0.0011 \pm 0.0001^{d}$ & $0.007 \pm 0.0034$ \\
\hline aTocopherol & $0.36 \pm 0.005^{\mathrm{cd}}$ & $0.007 \pm 0.00056^{d}$ & $0.0009 \pm 0.0005$ \\
\hline ঠTocopherol & $0.038 \pm 0.00023^{\mathrm{cd}}$ & $0.0001 \pm 0.00^{\mathrm{cd}}$ & $0.0009 \pm 0.0005$ \\
\hline Retinol & $0.0001 \pm 0.00006^{c}$ & $0.0002 \pm 0.00^{\mathrm{b}}$ & $0.0006 \pm 0.001$ \\
\hline retinol acetate & $0.0002 \pm 0.00001^{b}$ & $0.0001 \pm 0.00^{\mathrm{cd}}$ & - \\
\hline$\beta$-sitosterol & $0.45 \pm 0.0025^{d}$ & $0.008 \pm 0.00028^{\mathrm{cd}}$ & $0.07 \pm 0.008$ \\
\hline Stigmasterol & $0.1723 \pm 0.003^{d}$ & $0.020 \pm 0.0009^{c}$ & $0.03 \pm 0.011$ \\
\hline Ergosterol & $0.22 \pm 0.0041^{\mathrm{cd}}$ & $0.0021 \pm 0.01^{d}$ & $0.011 \pm 0.005$ \\
\hline
\end{tabular}

P:Pease, DH: D. hansenii, P+DH: Pease + D. hansenii, cd: $p<0.0001, d: p<0.001, c: p<0.01, b: p<0.05, a: p>0.05$

\begin{tabular}{|c|c|c|}
$\begin{array}{c}\text { Table 4: Flavonoid and resvertrol levels of P. sativum (Pease) prepared } \\
\text { with } \boldsymbol{D} \text {. hansenif }(\boldsymbol{\mu g} / \mathbf{1} \mathbf{~ g}) \text {. }\end{array}$ \\
\hline Flavonoids & $\mathbf{P}+\mathrm{DH}$ & $\mathbf{P}$ \\
\hline Rutin & - & - \\
\hline Myricetin & $0.00 \pm 0.00^{\text {d }}$ & $0.0001 \pm 0.01$ \\
\hline Morin & $0.00 \pm 0.00^{\text {d }}$ & $0.0001 \pm 0.00$ \\
\hline Catechin & $0.0009 \pm 0.001^{\text {cd }}$ & $0.044 \pm 0.003$ \\
\hline Naringin & $0.00 \pm 0.00^{\text {cd }}$ & $0.0008 \pm 0.02$ \\
\hline Resveratrol & - & - \\
\hline
\end{tabular}

P:Pease, DH: D. hansenii, $\mathrm{P}+\mathrm{DH}$ : Pease + D. hansenii, $c \mathrm{~d}: \mathrm{p}<0.0001, \mathrm{~d}: \mathrm{p}<0.001$

the increase is realized by vitamin and phytosterol production as a result of pease extract's positive effect on the development of $D$. hansenii.

\section{Flavonoid Contents and Radical Scavenging Properties}

It was detected that myricetin, morin, catechin, naringin were present in pease and the amount of catechin in this plant was higher than other phenolic compounds but, rutin, resveratrol were not present Table 4. However, it was detected that all present flavonoid compounds decreased in the pease extract prepared with $D$. hansenii at different levels with respect to the pease plant (control) $(p<0.0001, p<0.001)$. In conclusion, decreasing amount of all present phenolic compounds in the pease extract 


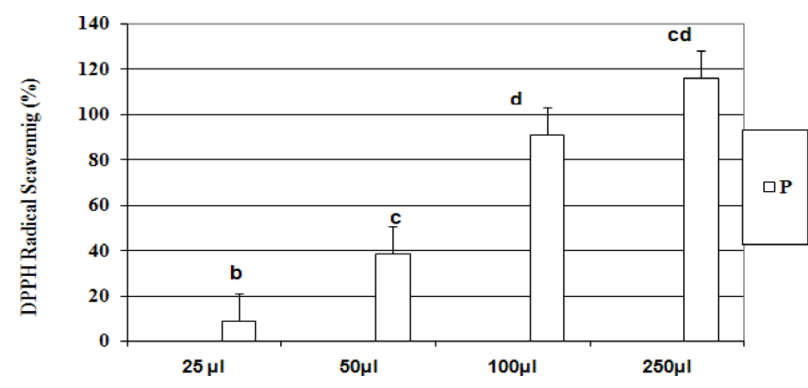

Figure 1: DPPH Radical scavenging activity of $P$. sativum (Pease) extract.

prepared with $D$. hansenii indicated that $D$. hansenii uses these compounds in pease

When DPPH ( $\alpha, \alpha$-Diphenyl- $\beta$-picrylhydrazyl) free radical scavenging effect of pease was analyzed, it was detected that increasingly it had an antioxidant effect and significant effect at $100,250 \mu \mathrm{l}$ concentration $(p<0.001)$ Figure 1.

\section{Antimicrobial Activity}

Antibacterial and antifungal effects of fatty acid extracts of pease used in the study are given in Table 6 . It was observed that these extracts inhibited developments of all of the microorganisms except $K$. pneumoniae. According to this, it was detected that it had very low levels of effect against microorganisms such as E. coli, S. aureus C. albicans (8.66-9.66 mm/inhibition zone) while it had significant antibacterial and antifungal activity over B. megaterium and C. glabrata $(16.66 \mathrm{~mm})$, Epidermophyton sp. $(17.66 \mathrm{~mm})$, Trichophyton sp. (18.66 mm).

On the other hand, P. sativum fatty acid extract prepared with $D$. hansenii inhibited at low rates the growth of B. megaterium E. coli $(9.33 \mathrm{~mm} /$ inhibition zone) however, they significant affect other bacteria types (E. coli and K. pneumoniae; $11.66 \mathrm{~mm} \mathrm{S.} \mathrm{aureus;} 24.66 \mathrm{~mm}$ ). In additon, it was detected that it had very high antifungal activity against $C$. albicans $(18.66 \mathrm{~mm}), C$. glabrata $(11.33 \mathrm{~mm})$, Epidermophyton sp. and Trichophyton sp. $(22.66 \mathrm{~mm})$. Moreover, $D$. hansenii fatty acid extracts specifically inhibited the development of yeasts and dermatophyte fungi $(10.33-21.33 \mathrm{~mm})$ also, they were effective against $S$. aureus and E. coli $(12.33 \mathrm{~mm})$ except K. pneumoniae and B. megaterium. Acording to it has shown clearly that these data supported results of fatty acid analyses of pease prepared with $D$. hansenii.

When the effect of vitamin extracts in P. sativum on the development of bacteria, yeasts and dermatophyte fungi was analyzed, it was observed that it had significant antimicrobial activity against all of the bacteria, yeasts and dermatophyte fungi $(21.66-33.66 \mathrm{~mm})$
It was detected that it had effect on a general decline on the development of bacteria, yeasts and dermatophyte fungi in vitamin extracts containing $D$. hansenii prepared from P. sativum. According to this, E. coli; $9.66 \mathrm{~mm}$, S. aureus; $8.33 \mathrm{~mm}$, C. albicans; $10.66 \mathrm{~mm}$, C. glabrata; $8.66 \mathrm{~mm}$, Epidermophyton sp.; $16.33 \mathrm{~mm}$, Trichophyton sp.; $14.66 \mathrm{~mm}$. however, they did not affect other bacteria types such as $K$. pneumoniae, B. megaterium. Also, it has shown clearly that these data supported results of vitamin analyses of pease prepared with $D$. hansenii. It is thought that the reason for this reductions is related to consumption by $D$. hansenii of these bioactive compounds have antimicrobial activity. On the other hand, $D$. hansenii vitamin extracts were effective at changing rates against all of the bacteria, yeasts and dermatophyte fungi $(8.33-13.66 \mathrm{~mm})$.

The flavonoid extracts of $P$. sativum were analyzed in terms of their antibacterial and antifungal activities, it was detected that it had very low levels of effect against yeasts and dermatophyte fungi such as C. albicans; C. glabrata, Epidermophyton sp. and Trichophyton sp. (8.0-9.66 mm/inhibition zone) while it did not have any activity on all of the bacteria Table.6 However, P. sativum extracts prepared with $D$. hansenii did not have any activity over all of the microorganisms except $B$. megaterium ( $8.33 \mathrm{~mm} /$ inhibition zone). Table. 5 Also, it has shown clearly that these data supported results of flavonoid analyses of pease prepared with $D$. hansenii. It is thought that the reason for this reductions is related to consumption by $D$. hansenii of these bioactive compounds have antimicrobial activity.

In our work, when antimicrobial activities of pease extracts containing $D$. hansenii were analyzed, it was observed that they had significant effect at changing rates against some of the bacteria and all of the yeasts and dermatophyte fungi with respect to control groups of fatty acid and vitamin extracts. This assertion supports the findings of this work. According to this, it has become evident that these data presented parallel results with the fatty acid, vitamin and phytosterol, flavonoid, and resveratrol analyses conducted in this study.

As previous researchers also indicated, sensitivity of microorganisms against chemotherapeutic materials differs from strain to strain $;^{23}$ therefore, some plant extracts may demonstrate at different levels antimicrobial activities. This assertion supports the findings of this study. In addition to, it has become evident that these data presented parallel results with the fatty acid, vitamin and phytosterol, flavonoid and resveratrol analyses conducted in this study. 


\begin{tabular}{|c|c|c|c|c|c|}
\hline \multirow[t]{3}{*}{ Microorganisms } & \multicolumn{5}{|c|}{ Inhibition zone (mm) } \\
\hline & \multicolumn{3}{|c|}{$\begin{array}{l}\text { Antimicrobial activities of fatty acid, vitamin and flavonoid } \\
\text { extracts of } P \text {. sativum }(\mathrm{mm}) \text { prepared with } D \text {. hansenii }(\mathrm{mm})\end{array}$} & \multicolumn{2}{|c|}{$\begin{array}{l}\text { Antimicrobial activities of fatty acid, } \\
\text { vitamin extracts of } D \text {. hansenii }(\mathrm{mm})\end{array}$} \\
\hline & Fatty acid & Vitamin & Flavonoid & FattyAcid & Vitamin \\
\hline E. coli & $11.66 \pm 0.33$ & $9.66 \pm 0.33$ & - & $12.33 \pm 0.03^{\mathrm{cd}}$ & $8.33 \pm 0.33$ \\
\hline K. pneumoniae & $11.66 \pm 0.88$ & - & - & - & $9.66 \pm 0.33$ \\
\hline B. megaterium & $9.33 \pm 0.33$ & & $-8.33 \pm 0.33^{b}$ & - & $9.66 \pm 0.33$ \\
\hline S. aureus & $24.66 \pm 0.88$ & $8.33 \pm 0.33$ & - & $12.33 \pm 0.03^{\mathrm{cd}}$ & $13.66 \pm 0.33^{\text {cd }}$ \\
\hline C. albicans & $18.66 \pm 0.33$ & $10.66 \pm 0.33$ & - & $11.33 \pm 0.03$ & $9.66 \pm 0.33$ \\
\hline C. glabrata & $11.33 \pm 0.33$ & $8.66 \pm 0.33$ & & $8.33 \pm 0.03$ & $9.66 \pm 0.33$ \\
\hline Epidermophyton sp. & $22.66 \pm 0.33$ & $16.33 \pm 0.33$ & - & $21.33 \pm 0.03^{c d}$ & $15.66 \pm 0.33^{c d}$ \\
\hline Trichophyton sp. & $22.66 \pm 0.88$ & $-14.66 \pm 0.33$ & - & $10.33 \pm 0.03^{d}$ & $11.66 \pm 0.33^{\mathrm{cd}}$ \\
\hline
\end{tabular}

\begin{tabular}{|c|c|c|c|c|c|c|}
\hline \multirow[t]{3}{*}{ Microorganisms } & \multicolumn{6}{|c|}{ Inhibition zone (mm) } \\
\hline & \multicolumn{3}{|c|}{ P. sativum } & \multicolumn{3}{|c|}{ Control } \\
\hline & Fatty acid & Vitamin & Flavonoid & Methanol & Hexane & Standart antibiotics \\
\hline E. coli & $8.66 \pm 0.33^{d}$ & $25.66 \pm 0.33^{\mathrm{cd}}$ & - & - & $15.33 \pm 0.3$ & $10.3 \pm 0.3^{* *}$ \\
\hline K. pneumoniae & - & $33.66 \pm 0.50^{\text {cd }}$ & - & - & $14.66 \pm 0.3$ & $9.6 \pm 0.3^{* *}$ \\
\hline B. megaterium & $16.66 \pm 0.33^{d}$ & $25.66 \pm 00.33^{\mathrm{cd}}$ & - & - & $13.3 \pm 0.4$ & $13.4 \pm 0.1^{* *}$ \\
\hline S. aureus & $8.66 \pm 0.33^{d b}$ & $28.66 \pm 0.33^{\mathrm{cd}}$ & - & - & $12 . .3 \pm 0.3$ & $9.3 \pm 0.3^{* *}$ \\
\hline C. albicans & $9.66 \pm 0.33^{b}$ & $22.66 \pm 0.33^{\mathrm{cd}}$ & $9.66 \pm 0.33^{c}$ & - & $17.0 \pm 001$ & $18.0 \pm 0.5^{*}$ \\
\hline C. glabrata & $16.66 \pm 0.33^{d}$ & $21.66 \pm 0.33^{\mathrm{cd}}$ & $9.66 \pm 0.33$ & - & $11.0 \pm 0.0$ & $12.6 \pm 0.3$ \\
\hline Epidermophyton sp. & $17.66 \pm 0.33^{d}$ & $24.66 \pm 0.33^{\mathrm{cd}}$ & $8.66 \pm 0.33^{b}$ & - & $9.3 \pm 0.3$ & NT \\
\hline Trichophyton sp. & $18.66 \pm 0.33^{\mathrm{cd}}$ & $21.66 \pm 0.33^{\mathrm{cd}}$ & $8.00 \pm 0.00^{a}$ & - & $17.3 \pm 0.3$ & NT \\
\hline
\end{tabular}

*:Nystatin (Antifungal, $30 \mu \mathrm{g} / \mathrm{disc}$ ), **:Streptomycin sulphate (antibacterial,10 $\mu \mathrm{g} / \mathrm{disc}$ ), Control (methanol and hexzane): $10 \mu \mathrm{L}, \mathrm{NT}:$ not tested

\section{DISCUSSION}

The probiotic dairy products are used in increasingly in developed countries. The use of such products in our country has crucial benefits from the point of overall community health. Especially consuming these in childhood will contribute to raising the new generations more healthy. ${ }^{24}$ Indeed, Milk and leavened milk products are commonly used in daily nutrition order in our country, and we have a significant agriculture power also. That's why our country where is rich in prebiotic sources has a potential for scientific researches. ${ }^{25}$

The Pease that is used as fresh and frozen contains $B_{1}$, $\mathrm{C}$ vitamins, protein, fiber and folic acid. It has a relaxing effect on the nervous system. ${ }^{26}$

It was specified in a study about the fatty acid profile of Pease that 18:2 (linoleic) was found as approximately $21 \% .^{27}$

It was stated in another study that the Pease extracts from Leguminaceae family have a higher coloration than other phenolic compounds and antioxidant activities and show a rich antioxidant feature based on the high phenolic content of pease. ${ }^{28}$ an analysis of antioxidant capacity of Pease on different varieties showed that ascorbic acid is existed based on this capacity. ${ }^{29}$

The primary lipid compounds of phospholipid and triacylglycerol of Pease extacts are in rates respectively $52.2-61.3 \%$ and $31.2-40.3 \%$, on the contrary, the other compounds are at low rates as well (5.6-9.2\%). Moreover, it is clearly seen in studies that the $\gamma$-tocopherol is at such a high level, $\alpha$ - and $\delta$ - tocopherol is at a low level; ${ }^{30}$ the Pease has a hypercholesterolemic effect on rats. $^{31}$

Any phenolic acids and flavone and flavonal glycosides were determined as a result of HPLC analysis on the ant oxidative characteristics and phenolic compound contents. ${ }^{32}$

According to these statement above, several studies done with pease supports these results. As a matter of fact the high antibacterial effect of pease ${ }^{33}$ is proven by a research about the antibacterial activity of the pease. 
The fact that consuming other beneficial nutrients such as vitamins, minerals, phenolic compounds together besides fiber while consuming fibrous foods consumed ${ }^{34}$ makes the study more meaningful. Recently, several other yeast strains belonging to the genera Saccharomyces, Debaryomyces, Torulaspora, Kluyveromyces, Pichia and Candida have also been shown to have probiotic potential in terms of their ability to survive simulated conditions of the gastrointestinal tract (GIT), and to adhere to different mammalian intestinal epithelial cells. ${ }^{35}$

Numerous past works have indicated the need to examine probiotics and prebiotics, but this is yet to be done about the effect of prebiotic food; Pease on the development of $D$. hansenii as one of the probiotic yeasts. Further more two studies are available in this direction that We made in terms of pre and probiotics relationship. ${ }^{36,37}$

Because of the significant effects of on the development of prebiotics and probiotics, the selection of the appropriate prebiotic substance is important in the production of food containing probiotic and prebiotic combinations. ${ }^{38}$ Now combining probiotics and prebiotics into "synbiotics" have potentia lto further enhance the immunosupportive effects. ${ }^{39}$

\section{CONCLUSION}

Confirming all these findings show that the probiotics and prebiotic are extremely efficient in verification by more extensive studies on humans will achieve a major improvement in health and economy. At the same time, this confirming process offer new participations for future studies to enlighten the issues like the relation of host-microorganism, proper prebiotic and the combination of proper probiotic-prebiotic (symbiotic).

\section{ACKNOWLEDGMENT}

This work was supported by FUBAP Firat University Scientific Research Project Coordinatorship (Project No 1909). We sincerely thank to Prof Dr Ökkeş Yılmaz due to support our experimental works.

\section{CONFLICT OF INTEREST}

The authors declare no conflict of interest.

\section{ABBREVIATION USED}

P: Pease; DH: D. hansenii; P+ DH: P. sativum (pease) extract prepared with D. hansenii; NT: not tested; HPLC: High performance liquid chromatography;
DPPH: $\alpha, \alpha$-Diphenyl- $\beta$-picrylhydrazyl; SHIMADZU GC 17 : Gas Chromatography device.

\section{REFERENCES}

1. Yılmaz M. Prebiyotikler ve Probiyotikler (derleme). J Curr Pediatr. 2004;2:142-5.

2. Gibson GR. Fibre and effects on probiotics (the prebiotic concept). Clin Nutr Suppl. 2004;1(2):25-31.

3. Guarner F, Malagelada JR. Gut flora in health and disease. Lancet. 2003;361:512-9.

4. Fanaro S, Chierici R, Guerrini P, Vigi V. Intestinal microflora in early infancy:composition and development. Acta Paediatr Suppl. 2003;91(s441): 48-55.

5. Yılmaz ÖA. Healthy diet in elderly-probiotics. Ege J Med. 2015;54:16-21

6. Özyurt HV, Ötleş S. Prebiyotikler: Metabolizma İçin Önemli Bir Gıda Bileşeni. Acad Food J. 2014;12(1):115-23.

7. Prebiyotiik Probiyotikler ve Besinsel Kaynakları. Kuran B. 2017. http://www. tavsiyeediyorum.com/makale_9341.htm [Acces date: 15.07.2012].

8. http://www.beslenme.saglik.gov.tr/content/files/yayinlar/kitaplar/beslenme_ bilgi_serisi_2/b11. Ff 2008.

9. Ochangco HS, Gamero A, Smith IM, Christensen JE, Jespersen L, Arneborq N. In vitro investigation of Debaryomyces hansenii strains for potential probiotic properties. World J Microbiol Biotechnol. 2016;32(9):141.

10. Haruto K. Assessment of wild type yeasts isolated from dairy origin as probiotic use, Urakami Foundation Memoirs. JSTA. 2003;11:19-23.

11. Hara A, Radin NS. Lipid extraction of tissues wth a low toxicity solvent. Anal Biochem. 1978;90(19):420-6

12. Christie WW. Gas chromatography and Iıpıds. The Oıl Pres Glaskow; 1992. Pp. 302.

13. Trrzicka E, Vecka M, Stankova B, Zak A. Analysis of fatty acids in plasma lipoproteins by gas chromatography flame ionisation detection Quantitative aspects. Anal Chimica Acta. 2002;465(1):337-350.

14. Katsanidis E, Addis PB. Novel HPLC analysis of tocopherols and cholesterol in tissue. Free Radic Biol Med. 1999;27:(11-12):1137-40.

15. Lopez-Cervantes J, Sanchez-Machado DI, Ríos-Vazquez NJ. Highperformance liquid chromatography method for the simultaneous quantification of retinol, a-tocopherol, and cholesterol in shrimp waste hydrolysate. J Chromatogr A. 2006;1105(1):135-9.

16. Brand-Williams W, Cuvelier ME, Berset C. Use of a free radical method to evaluate antioxidant activity. Lebensm Wiss Technol. 1995;28(1);25-30.

17. Hsu B, Coupar IM, Ng K. Antioxidant activity of hot water extract from the fruit of the Doum palm, Hyphaene thebaica. Food Chem. 2006;98(2):317-28.

18. $\mathrm{Zu} \mathrm{Y,} \mathrm{Li} \mathrm{C,} \mathrm{Fu} \mathrm{Y,} \mathrm{Zhao} \mathrm{C.} \mathrm{Simultaneous} \mathrm{determined} \mathrm{of} \mathrm{catechin,} \mathrm{rutin,}$ quercetin, kaempferol and isorhamnetin in teh extract of sea buckthorn (Hippophae rhamnoides L.) leaves by RP-HPLC with DAD. J of Pharma and Biomed Anal. 2006;41:714-9.

19. Alltech Chromatography. A Grace Company Catolog 600. Alltech Associates İnc. 2004. s497.

20. Özçelik S. Gıda mikrobiyolojisi laboratuar kılavuzu. Fırat Üniv Fen-Edebiyat Fak Yayın; No:1, Elazığ; 1992. 85s.

21. Collins CM, Lyne PM. Mikrobiyological methots. Butter Morths and Co (Publishers) Ltd. London; 1987. 450 pp.

22. Aydın S. The effect of nitrite on enhancement of alpha-amylase synthesis afforded by bacterial hemoglobin in genetically enginered $E$. coli illinois institute of technology Sikago- USA; 1999;21.

23. Kızıl G, Toker Z, Özen Ç, Aytekin C. The antimicrobial activity of essential oils of Hypericum scabrum, Hypericum scabroides and Hypericum triquetrifolium. Phytother Res Apr. 2004;18(4):339-41

24. Özden A. Gastro-İntestinal sistem ve probiyotik-prebiyotik synbiyotik. Güncel Gastroenterol Derg. 2005;9(3):124-33.

25. Molbay D, Çekin MD. The roles of probiotics and prebiotics. Türk Aile Hekim Derg. 1999;3(3-4):85-8.

26. www.fonksiyonelgida.net/sifalibitkiler.pdf 2010

27. Grela ER, Günter KD. Fatty acid composition and tocopherol content of some legume seeds. Anim Feed Sci Tech. 1995;52(3-4):325-31. 
28. XU Bj, Chang SKC. A Comparative Study on Phenolic Profiles and Antioxidant Activities of Legumes as Affected by Extraction Solvents. J Food Sci. 2007;72(2):159-66.

29. Nilsson J, Stegmark R, Akesson B. Total antioxidant capacity in different pea (Pisum sativum) varieties after blanching and freezing. Food Chem. 2004;86(4):501-7.

30. Yoshida H, Tomiyama Y, Saiki M, Mizushina Y. Tocopherol Content and Fatty Acid Distribution of Peas (Pisum sativum L.). J Am Oil Chem Soc. 2007;84(11):1031-8.

31. Agnieszka T, Bozena B. Antioxidant activity of crude tannins of pea (Pisum sativum L.) seed coat and their hypocholesterolemic effect in rats. PJ Food Nutr Sci. 2002;11(3):33-8.

32. Troszyska A, Estrella I, Lopez-Amores ML, Hernandez T. Antioxidant Activity of Pea (Pisum sativum L.) Seed Coat Acetone Extract. Lebensm-Wiss Technol. 2002;35(2):158-64.

33. Saed S, Perween T. Antibacterial activities of Mentha piperita, Pisum sativum and Momordica charantla. Pak J Bot. 2005;37(4):997-1001
34. Nehir EI S. 2016. Gıda Bileşenlerinin Beslenme Açısından Önemi. http://food. ege.edu.tr/files/dersler/beslenme/2016_beslenme_ders\%20notu.pdf. Ege Üniverstesi Beslenme Ders Notu, s.21

35. Zivkovic M, Cadez N, Uroic K, Miljkovic M, Tolinacki M, Dousova P, et al. Evaluation of probiotic potential of yeasts isolated from traditional cheeses manufactured in Serbia and Croatia. JICEP. 2015;4(1):12-8.

36. Erecevit P, Kırbağ S, Yılmaz Ö. Determination of Phytochemical Characteristics of Zea mays (Corn) Extracted with Saccharomyces boulardii. Chem Nat Compd. 2013;49:12-6.

37. Erecevit P, Kırbağ S, Zengin F. Determination of Phytochemical Contents of Avena sativa (oat) and Its Impact on Debaryomyces hansenii. Proc Natl Acad Sci. India Sect B Biol Sci. 2013;84(2):365-71.

38. Şener A, Temiz A, Özmen TS, Bağcı U. Çeşitli Prebiyotiklerin Bifidobacterium animalis Subsp. Lactis Bb-12'nin Gelişimi ve Asitlik Geliştirme Özelliği Üzerine in vitro Etkileri. Türkiye 10. Gıda Kongresi. 2008;21-23 Mayıs Erzurum, 889-892.

39. Singh SB, Jairath S. Prebiotics, probiotics and synbiotics: an overview. J Pharm Educ Res. 2010;1(2):13-36.

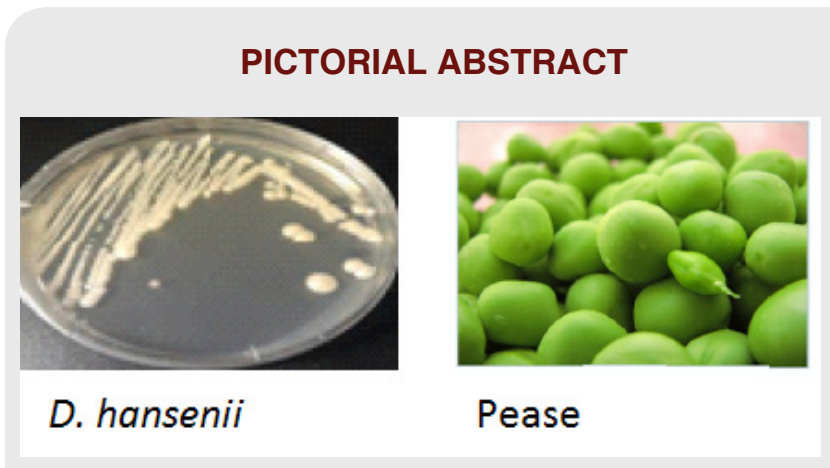

About Authors

Pınar Erecevit: She is Assistant professor at Munzur University. She has been study in Munzur University. He did his doctorate and master's degree at the Firat University. He made his doctor (PhD) on general biology (biochemistry, food microbiology). She published many scientific articles; on antimicrobial activity of traditional plants, bioactive compounds, probiotics, prebiotics, fungi.

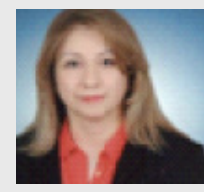

Prof. Dr. Sevda Kirbağ: She is Professor in Department of Biology at Firat University. She has made hers expertise; biology, mycology, phytochemicals, molecular biology, microbiology antimicrobial susceptibility test.

Cite this article: Erecevit P, Kirbag S. Determining the Phytochemical Parameters of Pisum sativum (pease) and Effects on the Development of Debaryomyces hansenii. Indian J of Pharmaceutical Education and Research. 2017;51(4S):S637-S44. 